\title{
CHINESE GOVERNMENT'S FORMAL INSTITUTIONAL INFLUENCE ON CORPORATE ENVIRONMENTAL MANAGEMENT
}

\author{
Anna L. Rowe ${ }^{1}$ \\ Curtin University of Technology, Western Australia
}

James Guthrie ${ }^{2}$

The Sydney University, NSW

$\&$

Bologna University, Italy

Accepted for the

$1^{\text {st }}$ International Conference on Sustainable Management of Public \& Not for Profit Organisations Conference

1 - 3 July 2009

University of Bologna, Italy

${ }^{1}$ Dr Anna L. Rowe

Graduate School of Business

Curtin University of Technology

GPO Box U1987

Perth 6845

Western Australia

Email: Anna.Rowe@gsb.curtin.edu.au
${ }^{2}$ Prof. James E. Guthrie

Accounting and Business Law,

University of Sydney

Sydney

NSW

Australia

Email: J.Guthrie@econ.usyd.edu.au

The authors wish to thank Professor Alma Whiteley, Curtin University, Professor Roger Burritt, University of South Australia, Professor Walter Wehrmeyer, Centre for Environmental Strategy, University of Surrey, UK, and the anonymous reviewer for their constructive comments. Also, Fiona Crawford, the Sydney University and Julz Stevens, Bologna University, Italy. 


\title{
CHINESE GOVERNMENT'S FORMAL INSTITUTIONAL INFLUENCE ON CORPORATE ENVIRONMENTAL MANAGEMENT
}

\begin{abstract}
Due to the gravity of its environmental problems where 16 of the 20 most polluted cities on earth reside in China, the national development strategy for environmental protection has become more focused since the Sixth National conference on Environmental Protection in 2006. The government has set the strategic goal of striving for a harmonious 'Xiaokang' Society by the year 2020. The State Environmental Protection Administration (SEPA) is keen to encourage the business sector to engage in environmental initiatives.

This paper is part of a larger empirical study grounded on senior managers' perceptions of corporate environmental management (CEM) in the People's Republic of China (PRC). To explore the emerging phenomenon of CEM in Shanghai, an appropriate research methodology is used. 'Coercive Government Institutional Involvements' emerged as one of the major influencing factors in corporate environmental initiatives. The State regulatory regime has been perceived by Chinese managers to be the most influential, most complex, and least predictable on organisational environmental performance.

The study is limited to an investigation of CEM in Shanghai but the implications of this exploratory research is that environmental management systems that work in developed nations should not be directly transplanted to developing nations without considering institutional contexts. Business enterprises operating in the PRC needs to be vigilant and aware that notwithstanding, its dynamic economic boom and modernisation, the state has tremendous influence.
\end{abstract}

Keywords: China, Corporate Environmental Management, State Development Strategy; and Institutional Theory. 


\section{CHINESE GOVERNMENT'S FORMAL INSTITUTIONAL INFLUENCE ON CORPORATE ENVIRONMENTAL MANAGEMENT}

\section{INTRODUCTION}

During the past two decades, the People's Republic of China (PRC) has been enjoying an incredible GDP growth rate of 9-10\% per annum. Notwithstanding the current massive global economic downturn (i.e., the Economist Intelligence Unit expects real GDP growth to slow sharply to just 6\% in 2009), such an unbridled economic growth has alleviated millions of people out of poverty but is taxing the planet. China is home to 16 of the 20 most polluted cities on earth (World Bank, 2001).

The PRC government has set the goal of striving for a harmonious 'Xiaokang' Society by the year 2020. In achieving the goal of developing national economy and protecting ecological environment whilst maintaining social equity, China will need to quadruple its gross national product (GNP) of 2000. This will cause enormous challenges in managing depletion of natural resources and environmental pollution. As the most populous nation on earth with an insatiable appetite for natural resources to boost its economic growth, therefore the Chinese State has a prominent role in solving global environmental challenges (Diener and Rowe, 2007).

In response to the severity of its environmental problems, China has enacted and implemented a series of policies, principles, regulations and laws since the 1970s. Certain strategic policies such as the legally mandated environmental standards can coercively be imposed upon business enterprises. The State regulatory regime has been perceived by Chinese managers to be the most influential, most complex, and least predictable on organisational performance (Tan and Litschert 1994). Hence, it is imperative to understand senior managers' perceptions of 'Coercive Government Institutional Involvements' that emerged as one of the major influencing factors in corporate environmental initiatives (Rowe and Guthrie, 2007).

The paper is structured as follows: the following Section two provides a brief background of the Chinese Government's management of environmental degradation, followed in Section 3 by the rationale for utilising the chosen research methodology 
to explore senior managers' perceptions of corporate environmental management (CEM). Section 4 provides the findings from this empirical study about the 'Coercive Government Institutional Involvements' that emerged. Section 5 provides a discussion and the paper concludes in Section 6 with some implications and recommendations for future research.

\section{BACKGROUND}

The 1972 United Nations Conference on the Human Environment in Stockholm was a turning point for China's environmental management efforts. Since then, a fundamental national environmental policy and legislative structure have been gradually established. This led to China's first National Environmental Protection (NEP) Conference in August 1973 in Beijing. Environmental Protection Offices (EPOs) were established in May 1974, which pronounced the first PRC's environmental regulation popularly known as San Tong Shi (STS), interpreted as the ‘three simultaneous regulations’ or ‘three synchronizations’ (Zhang 2001).

The promulgation of the 'Environmental Protection Law for trial implementation' and formation of the EPOs in the late 1970s managed the environmental policies, laws, regulations and standards. By the turn of the Millennium, China had enacted fortythree environmental related laws since 1979, namely - six environmental protection laws, nine resource conservation laws and twenty-eight pieces of environmental administrative regulations (Zhang 2001).

In recent years, the "Cleaner Production Promotion Act" was enacted requiring industrial enterprises to implement cleaner production for environmental improvement (Guo 2005). On 16 June 2003, the State Environmental Protection Administration (SEPA) promulgated the "Regulations of Environmental Inspection on Companies accessing to or Refinance from Stock Market." It aims to prevent environmental risks associated with listed companies from heavy polluting industries (e.g., metal, chemistry, oil, coal, and constructions).

On 5 November 2003, the SEPA issued the "Bulletin on Information Disclosure of Corporate Environmental Performance” (SEPA 2003). This regulation requires noncompliant companies to produce environmental reporting to the public allowing the 
Environmental Protection Bureau (EPB) to release the names of these non-compliant enterprises to the public through the media (e.g., newspapers, television and websites).

In February 2005, the Standing Committee of National People's Congress of China (SCNPC 2005) promulgated "The Renewable Energy Law” which was enforceable from 1 January 2006. China's National Eleventh Five-Year Program (2006-2010) for National Economic and Social Development, introduced in October 2005, will enhance China's environmental policy and legislation with more stringent environmental standards.

During the April 2006 national conference on environmental protection, Premier Wen Jiabao reaffirmed the strategic importance of the environment (China Daily, 18 April 2006). In setting priorities for environmental protection, Premier Wen stressed that officials will be assessed on their environmental performance. Whilst targets for economic growth were easily met in the PRC's $10^{\text {th }}$ Five-Year Plan (2001-2005), the same cannot be reported for major environmental protection objectives. This was attributable to "lack of awareness, insufficient planning, illogical industrial structure and a weak legal framework” in some regions (Premier Wen, cited in China Daily, 18 April, 2006).

According to Li and Fung Research Centre (2005), China's current 11th Five-Year Program (2006-2010) will concentrate on the "people first" principle, thereby focusing on the issues of innovation, sustainability, social harmony, wealth sharing, economic growth, conservation and quality over quantity. Rowe's (2008) evolutionary 'epic' of China's Environmental Management Institutions” provides a historiography analysis of the PRC's government's advancement in tackling complex environmental sustainability that impacts on business enterprises operating in this fast growing economic power house.

Rowe (2008) research one outstanding issue - state intervention in the environment via rules, directives and legislations, but what impact does that have at the organisational level and CEM? This paper's aim is to examine perceptions of senior managers in Shanghai as to the impact of State environmental intervention on their 
actions and organisation. The following section outlines the research methodology followed. However, to what extent do organisations perceive the role of the Chinese government in influencing their CEM in Shanghai?

\section{RESEARCH METHODOLOGY}

To investigate senior managers' perception of the emerging phenomenon of CEM in Shanghai, constructivist ontology was chosen using a modified grounded research approach (Strauss and Corbin 1990; 1994; Whiteley 2004). The constructivist paradigm can help senior managers and policy-makers discover what is happening, and why organizational actors do what they do (Parker and Roffey 1997), thereby contributing to an understanding of CEM activities.

From the assumptions of constructivism ontology, the appropriate epistemology is therefore interpretivist (Guba and Lincoln 1994; Lincoln and Guba 2000). The 'realities' presented by the respondents must be interpreted and understood (verstehen), rather than empirically measured, and explained (erklären).

Multiple case study method was the research strategy that facilitated the understanding of the dynamics of the senior managers' response to CEM within their organisational case settings. The case context allowed the researcher to use 'controlled opportunism' to respond flexibly to discoveries made in collecting emerging data (Dutton and Dukerich 1991; Eisenhardt 1989 p. 539). Whilst case studies can combine data collection methods such as archives, interviews, questionnaires, and observations, and the evidence may be qualitative (e.g., words), quantitative (i.e., numbers) or both, this study focused on qualitative (e.g., text, interview and observation) evidence, which was collected in interaction with senior managers.

This multiple case study method had been guided by grounded research approach using systematic data preparation and management (Strauss and Corbin 1990; 1994; Whiteley 2004). A grounded research approach “is a general methodology for developing theory that is grounded in the data systematically gathered and analysed. Theory evolves during actual research, and it does this through continuous interplay between analysis and data collection” (Strauss and Corbin 1994 p. 273). 
Whilst a modified version of the original grounded theory was adopted for this exploratory study, the basic framework was kept in terms of allowing important responses to emerge the case studies institutionalised settings. This allowed the sifting and analysis of a large amount of data in non-standard and unpredictable formats.

Senior managers and executives from fifteen enterprises were interviewed between 2001 and 2005. Further informal contacts in Shanghai were made in 2007. According to the United Nations Educational, Scientific and Cultural Organisation (UNESCO) office in Beijing “company managers are a key target group of major importance to the environmental situation in China” (Hebel 2003, forward).

The interviews were a way of tapping the thoughts of subjects and examining how they each perceived the reality of CEM and the meaning that they construed around that. In order to reflect the diversity of companies in Shanghai, the fifteen organisational cases selected for this research were of different types and sizes.

The interviews were audio taped (whenever possible) and field notes were immediately documented within 24 hours, so as not to lose the vital nuances and cues observed. The taped interviews were transcribed and rigorously reviewed for errors by both the researchers and Chinese translators. Tapes were carefully listened to following the Strauss and Corbin (1990) framework, and corrections were made. The trustworthiness of transcripts was carefully assessed following Poland's (1995) methods.

Only the views of the most senior managers/executives of each of the organisations were taken into account for each case (unless contrary views by majority of managers prevailed), while the data gathered from the rest of the managers (within the same enterprise) took on a supportive role. Hence, prolonged engagement added to the rigour and trustworthiness of the data collected in Shanghai (Lincoln and Guba1985). Full details of the research methods, samples and the interviews are explained in detail in Rowe and Guthrie (2007). This paper uses part of the empirics from the wider study to specifically examine the issue of coercive government institutional involvements in CEM as perceived by senior managers in Shanghai. 


\section{COERCIVE GOVERNMENT INSTITUTIONAL INVOLVEMENTS}

In this empirical study, coercive government institutional involvements emerged as one of the major influencing factors of CEM. What is to follow in this section is: 4.1 State Strategic Environmental Polices and Rules; and 4.2 Preferred Environmental Strategies

\subsection{State Strategic Environmental Policies and Rules}

Respondents were of the opinion that problems relating to the environment were best resolved by the government at the macro-level. However, when asked about 'who is responsible for environmental protection?' - the respondents were equally divided in suggesting that environmental responsibility rests with both the government and every individual. And yet, 73\% of those interviewed, emphasised the importance of Chinese government's institutional role in solving environmental problems. It was expected of the government institutions to address China's environmental concerns by establishing State strategic environmental policies, regulating environmental laws and rules, and monitoring and enforcing them. The major concept of coercive government institutional involvements (Rowe 2008) that is perceived to influence CEM surfaced from some of the following quotations ${ }^{3}$ by participants.

// The government is not doing enough to solve environmental degradation problems // Chinese government appears to be reactive rather than proactive to environmental degradation problems // The government may pressure other enterprises to consider environmental protection policies // government is seen to be implementing its environmental policies // it is a national issue, macro policy // the governments have financial problems, not enough funds to solve environmental problems // the government is aware but because of the short of funds, cannot afford big scale environmental protection // under a wise government, the state, we can do it // we know that the government's policy

\footnotetext{
${ }^{3}$ Each interview was recorded in either English or Chinese; the researcher understood and spoke Mandarin, and then the material was translated. The interview date is presented mixed together for ethical reasons and also to consolidate the sample of senior manager's perceptions.
} 
has a long term plan. It considers environmental protection at the same time as development takes place. //

As highlighted from these selected quotations, there were recurrent emphases on the influence of government institutional involvements in CEM.

Figure 1 demonstrates the linkages between the supporting categories i.e., (macro environmental policies and laws; compliance; and monitoring and enforcements) and the conceptual theme of 'coercive government institutional involvements' that influenced CEM.

Figure 1: Coercive Government Institutional Involvement

$\underline{\text { Categories }}$

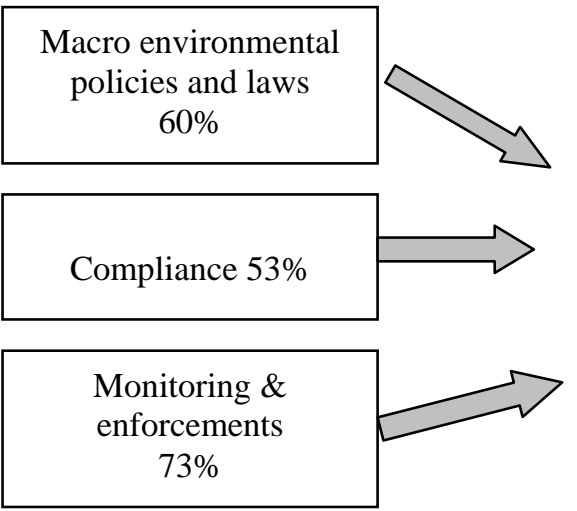

Concept

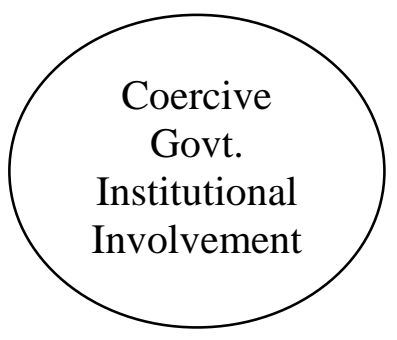

The conceptual theme of coercive government institutional involvements in CEM was supported by three main categories - macro environmental policies and laws (60\% of companies); compliance with environmental legislations (53\% of companies); and monitoring and enforcement (73\% of companies). From the perspective of the senior managers, the major concept of coercive government institutional involvements in turn, influenced CEM.

The pivotal role of Chinese government's institutional involvements in macro environmental policies and laws emerged very early in the research process. The meaning of 'environmental management' appears to take on a command and control notion. When requested to draw attention to the environmental management concerns 
challenging organizations in Shanghai, several Chinese senior managers tended to respond from the perspective of barriers encountered for the designing and implementation of environmental protection plans, referring to the state's Environmental Protection Policy in China.

When literally translated ${ }^{4}$, Huan Jing (environment) Guan Li (management) can be taken to mean 'controlling ambiance' such as atmospheric air and water. Searching through the Chinese environmental management literature, the terminology Huan Jing Guan $\mathrm{Li}$ did not appear to be commonly used other than in a journal by the same name. By contrast, environmental 'protection' (Huan Jing Bao $\mathrm{Hu}$ ) and environmental 'policy' (Huan Jing Zheng Ce) have frequently appeared in Chinese press articles and the terms were commonly spoken by respondents in reference to environmental management issues in Shanghai (Rowe 2006).

Such a command and control inference of environmental management at the public macro-level was evidence by some of the following responses (emphasis in bold) to the question as to whether their enterprises had any environmental policies (Rowe 2006, p. 108).

\section{// Environment policies, that is the political and economic environment // has to comply with environmental laws and regulations in all its projects. We have been aggressively developing new market areas and give preferential funding policies to prospective rising industries, such as high-tech..., green agriculture and environmental friendly projects// I think it is possibly due to the fact that it is a national issue, macro policy //}

The above mentioned quotations by respondents in support of the macro-level environmental policies and compliance-oriented views of environmental management, further supports the emphasis on 'Coercive Government Institutional Involvements'. The findings from this study also revealed that the preferred environmental solutions

\footnotetext{
${ }^{4}$ The researcher's hosts in China (academics from Shanghai University of Finance and Economics) and business associates provided valuable Mandarin version of 'environmental management' - Huan Jing Guan Li.
} 
of senior managers included: 'coercive regulatory instruments' such as, State environmental policies, laws and enforcements.

Through constant comparison and amalgamation of related categories during the iterative process of coding, axial-coding and analysis in accordance with Strauss and Corbin (1990), the categories for 'compliance' and 'manipulative capture' were collapsed and merged with the major category on 'compliance'.

Extracts from respondents of $73 \%$ of the companies interviewed specifically voiced their concerns in relation to the monitoring and enforcements category (with emphasis highlighted in bold) included the following:

// The scale of China's land mass is so huge that it is simply a logistical problem attempting to monitor for environmental compliance. Rules and penalties situation not very effective. Monitoring problems due to periodical investigations at a certain point in time, not a continuous on-going process // ...the lack of enforcement is a disappointment // The environmental protection board is weak and cannot enforce environmental rules and regulations. They require technology transfer and more government support to protect the environment // I doubt the government is efficient, and you have a conflict of interest. Here the government owns large amount of these heavy industries. These are the nastiest polluters // I actually think China has... some fairly good regulations, what is lacking in many cases is the enforcement //

Reflected in the following quotations were the concerns of $20 \%$ of participating companies who felt that there were unequal enforcements of environmental standards for those larger or foreign corporations in comparison with the financially weaker, smaller or state-owned-enterprises (SOEs). The findings in this study confirm the view expressed in the literature (e.g., Ferris and Zhang 2002; Ma and Ortolano 2000).

// Well, the government is already enforcing very strict environmental regulations on foreign investor enterprises in China. I think the government should also enforce those regulations with local state owned enterprises. // one action that could be taken, is to enforce the existing regulations uniformly 
across the whole industry of all sizes, of all origins who, be it multinational, be it SOEs, be it a local, whatever. // I would believe that you would see a tremendous improvement for the existing regulations to be finally enforced. // ... different kind of company has different treatments by government. //

These respondents were of the impression that State environmental standard enforcement was not uniform and varied across different economic sectors. The experience of foreign investors in China revealed that in general, foreign organizations were more stringently regulated than their local counterparts (interviews \#11, \#12 and \#16). This is in part, due to Chinese regulators' perceptions (SMEPB officials, pers. Comm..) that these companies from developed nations come from more advanced environmental management background with access to more sophisticated technologies, and should therefore operate at a higher environmental standard than their counterparts in China (Ferris and Zhang, 2002). Besides, foreign invested enterprises are seen as having the finance to install and operate appropriate environmental controls (interviews \#11, \#10, \#12 and \#16).

\subsection{Preferred Environmental Strategies}

Also, results reported in this paper indicated that senior managers and executives preferred solutions for China's environmental problems ranged from the command and control strategy of government's coercive regulatory instruments (60\% of organisations), to a strategy of using communicative instruments such as public awareness education (53\%) and market based incentives such as user taxes and tradable permits (40\%). Extracts of some of these quotations from which these findings were derived are stated as follows:

// Perhaps, imposing greater penalties and increasing resource prices, e.g., water and electricity rates // environmental taxes to increase // fund environmental protection schemes ... use environmental taxes to fund // government must increase regulations, offers positive incentives, impose greater penalties, and develop cleaner technologies // environmental awareness // require a lot more education and public awareness // TV and newspaper media are doing a good job promoting public awareness // public pressure may 
work // educating people to be environmental aware // Must include the cost of environmental degradation in pricing ... internalising external costs? // we have no environmental protection problems ... the officials must enforce greater rules on larger companies. //

In conclusion, the findings of our in-depth investigation were similar to the results of another study (Fryxell and Lo 2002) in regards to respondents' preferences for the 'command and control' regulatory instruments to curtail environmental degradation in China. In a survey of managerial preferences for policy mechanisms used to address environmental problems, managers from Beijing, Dalian and Guangzhou favoured regulatory instruments, placing less faith in communicative and market instruments (Fryxell and Lo 2002).

\section{DISCUSSION}

Findings from this study indicating the key role of the States institutional involvement in environmental management is not surprising. Governments play a prominent institutional role in CEM practices and are referred to in both institutional and environmental research (e.g., Berman et al. 1999; Hoffman 2001; Shrivastava 1995). Government institutional bodies are able to establish laws that bind organizations to certain practices and procedures. Andrews (1998), in a survey of Fortune 500 CEOs in 1995, found that coercive legal requirements and public perceptions (i.e., reputations) were most important in driving environmental business strategy.

It is evident from this study and rooted in the literature (e.g., Green and Yip 1993; Ma and Ortolano 2000; Ross 1994; Zhang 1997) that China has a significant environmental legislation in place that has been developed in the last two decades. China's constitution (Article 9) establishes the State's duty to conserve natural resources and wildlife, and Article 10 establishes the duty of persons and organizations to ensure rational land use (Ma and Ortolano 2000).

However, in practice, the findings in this study echoed what the literature indicated (Ma and Ortolano 2000; Zhang and Wen, 2008) - that is, the weak monitoring and enforcements of environmental laws and rules has hampered the success of the central government's environmental policy. For instance, interview \#16 summarised this 
succinctly (with emphasis added): "I actually think China has... some fairly good regulations, what is lacking in many cases is the enforcement." This gap between China’s “sophisticated set of regulatory programs” (Ma and Ortolano, 2000, p. 8) and the lack of stringent enforcement of environmental laws and rules has been widely cited by various authors (e.g., Ferris and Zhang 2002; Green and Yip 1993; Ross 1994; Stover 2000; Tang et al. 1997; Zhang and Wen 2008).

According to institutional theory, (Oliver 1991; Tolbert and Zucker 1983) penalties and fines for non-compliance behaviour do not daunt organizations if government enforcement of environmental protection regulations and rules are perceived to be weak. This is attributable to companies' reluctance to conform to environmental protection regulations when these rules and regulations are not widely diffused and accepted as the norm. Hence, corporations are less likely to mimic 'best practices' in CEM.

Enforcement of environmental rules on polluting enterprises such as the SOEs were found to be problematic in this study and this lends support to the literature (Ma and Ortolano 2000; Wong and Chan 1996). There were economic, environmental and social implications in closing down these polluting Chinese SOEs, as they were traditionally responsible for paying retirement pensions and for providing workers with housing, health care and other social supports. This legacy of the "iron rice bowl” concept regarding lifetime employment expected by many SOEs workers still persisted late last century (Hughes 2002; Whiteley et al. 2000, p. 9), although to a lesser degree in contemporary China.

However, the large iconic listed SOEs are seen to be actively engaging in CEM and disclosing their efforts (e.g., China Petroleum \& Chemical Corporation, CNOOC and Sinochem International Corporation). This is probably attributable to conforming with global institutional pressures (DiMaggio and Powell 1991) in legitimising their licence to practice (Deegan 2002; Mathews 1997) due to their size and public visibility.

The SEPA estimated that at the beginning of the century, Chinese industry was a primary source of pollution, accounting for about $40 \%$ of the nation's water pollution 
and about $80 \%$ of its air pollution (Wang et al. 2004). State enterprises in China pollute more per unit of output than non-state organizations and usually have lower operating efficiency utilizing older technologies (World Bank 1997). The SOE issue may explain Shenzhen's success in meeting standards as it is a free-market Special Economic Zone with few SOEs (East Asian Executive Reports 1999). However, the Shanghai SOEs interviewed and observed in this study were more technologically advanced and had privileged access to funding for environmental upgrades from the state and international institutions (e.g., the Asian Development Bank and World Bank).

In general, potentials for enforcement problems stem from the fact that municipal environmental protection authorities are mainly responsible for environmental enforcement activities in China. However, they are often less responsive to State Environmental Protection Administration (SEPA) than to the local governments, who frequently are major shareholders of polluting SOEs, creating an inherent conflict of interest (interview \#11;Green and Yip 1993; Stover 2000). Many local governments are also concerned about unemployment that will result if they close down polluting factories or mines. Some localities may even ignore the environmental laws altogether as the traditional Chinese proverb goes: "heaven is high and the emperor is far away."

Zhang et al, (1999) attribute this weak enforcement of environmental policies and regulations to insufficient incentives and inadequate resources (e.g., funding and technology) for polluting enterprises to improve their environmental practices and for the authorities to compel these organisations to comply. The SEPA officials noted that a major obstacle to enforcement involves the large, financially weak SOEs, which are among the worst polluters, with outdated equipments and insufficient resources to modernize or implement pollution control (China Daily, 2002).

To help understand the implementation gap between the good intentions of Chinese State institutional involvement (through macro environmental policies, compliance, monitoring and enforcement), and weak compliance due to lack of efficient monitoring and enforcement of environmental policies and laws, institutional constraints as a theoretical concept has been used to explain this phenomenon (Tang et al. 1997; Tsai and Child 1997). As explained above, institutional theory is a 
plausible explanation for the resistance to widespread CEM in Shanghai. Institutional theoretical constraints explain in part, why China's "sophisticated set of regulatory programs” (Ma and Ortolano, 2000, p. 8), did not translate to overall CEM.

Undisputedly, the Chinese government's past regulatory strategies have increased its effort to clean up the country's air, land, water and in attempting to prevent further environmental degradation. However, until CEM becomes an institutional 'norm' in doing business and is widely embraced by industry, most organisations will continue to accept the status quo - business as usual scenario for CEM.

\section{CONCLUSION}

This paper reports on an empirical study grounded in senior managers' perceptions of CEM in the PRC. 'Coercive Government Institutional Involvements' emerged as one of the major influencing factors in the empirical study of corporate environmental initiatives. This resonates well with the specialised literature as the State is a set of formal environmental institutions that can define the rules for corporate behaviour (DiMaggio and Powell 1991). Consequently, Chinese companies are disclosing environmental information mainly to alleviate the concerns from the government (Liu and Anbumozhi, 2009). Governments are the most prominent mechanism capable of establishing laws that bind enterprises to certain practices and procedures (Shrivastava 1995; Hoffman 2001; Rowe 2006).

However, the empirical findings from the interviews and observations suggest that the government's enforcement of compliance to environmental protection regulations appears to be spatial and ineffective. Hence, organisations in Shanghai were not deterred by the sanctions for non-compliance behaviour. For that reason, leading edge CEM activities might not be swiftly imitated or embraced. Thus, for organisations in emerging nations such as China, the institutional norm in environmental protection among most corporations is to adopt the "business as usual” scenario.

In the current study, senior executives in Shanghai advocated the following preferred environmental strategies to encourage CEM: greater government's coercive regulatory instruments (60\% of companies); better communicative instruments such as greater transparency, public awareness education and media (53\%); and market 
based incentives such as user taxes and tradable permits (40\%). The findings echo several authors' suggestions that whilst governments play the dominant role in the formal institutional mechanism of environmental management, it can be enhanced through market promotion and public participation (Zhang et al. 2008; Zhang and Wen 2008).

However, there are certain limitations that need to be noted. The study is limited to an investigation of CEM in Shanghai, but the implications of this exploratory research is that environmental management systems and standards that work in developed nations should not be directly transplanted to developing nations without considering institutional contexts.

Emanating from this study where the government is the major institutional actor, future research would heighten our understanding as to whether the process of initiating a shift towards environmental sustainability differs from the more developed economies. The results of the PRC government's institutional impact on CEM, including its formal environmental laws and rules that influence (or constrain) the actions of business enterprises and managers within these institutions, form the foundation upon which future studies can be expanded.

As can be observed from this study, the magnitude of China's environmental challenges will make this most populous nation on earth a vast market for environmental management opportunities such as environmental technology, services and products. Meeting these environmental challenges will be economically and socially daunting. Nevertheless, as expressed by one senior manager of a SOE who concluded that: “under a wise government, the State, we can do it” (interview \#21). 


\section{REFERENCE}

Andrews, C. 1998. "Environmental business strategy: Corporate leaders' perceptions." Society and Natural Resources 11:531-540.

Berman, Shawn L, Andrew C Wicks, Suresh Kotha and Thomas M Jones. 1999. "Does stakeholder orientation matter? The relationship between stakeholder management models and firm financial performance." Academy of Management Journal 42(5):488-506.

China Daily. 2002. "World Bank warns against bad policies." In Chung kuo jih pao. North American Edition. New York.

China Daily. 2006. "Wen sets environment protection goals." In China Daily. Beijing.

Deegan, Craig. 2002. "The legitimising effect of social and environmental disclosures - A theoretical foundation." Accounting, Auditing \& Accountability Journal 15(3):282-311.

Diener, Betty and Anna Rowe. 2007. "China: The challenges of economic growth and environmental sustainability." Greener Management International (GMI Special Issue 50):5-9.

DiMaggio, P and W. Powell. 1991. "Introduction." In The new institutionalism in organizational analysis, eds. W Powell and P. DiMaggio. Chicago: University of Chicago Press.

Donaldson, T and L E Preston. 1995. "The Stakeholder Theory of the Corporation: Concepts, Evidence and Implications." Academy of Management Review 20(1):65-91.

Dutton, Jane E. and Janet M Dukerich. 1991. "Keeping an Eye on the Mirror: Image and Identity in Organizational Adaptation." Academy of Management Journal 34(3):517-554.

East Asian Executive Reports. 1999. "China's environmental problems: Needs, spending, enforcement." East Asian Executive Reports 21(4):16-17.

Eisenhardt, Kathleen M. 1989. "Building Theories from Case Study Research." Academy of Management Review 14(4):532-550.

Ferris, Richard J Jr and Hongjun Zhang. 2002. "The challenges of reforming an environmental legal culture: Assessing the status quo and looking at postWTO admission challenges for the People's Republic of China." Georgetown International Environmental Law Review; 14(3):429-460.

Fryxell, G. E. and C. W. H. Lo. 2002. "Preferences for dealing with environmental problems: an empirical study of managers in three mainland Chinese cities." Journal of Environmental Management 64(1):35-47.

Glaser, B. 1978. Theoretical Sensitivity. Mill Valley, CA: Sociology Press.

Green, David and Sandra Yip. 1993. "China Environmental Challenge." International Corporate Law Nov (30):45-53.

Guba, E G and Y S Lincoln. 1994. "Competing paradigms and qualitative research." In Handbook of qualitative research, eds. N K Denzin and Y S Lincoln. Thousand Oaks, C.A.: Sage publications.

Guo, Peiyuan. 2005. "Corporate environmental reporting and disclosure in China." In CSR Asia 2005, June 2005, ed. Richard Welford. Beijing: Tsinghua University. 
Hebel, Axel. 2003. "Foreword." In Greening Chinese business : barriers, trends and opportunities for environmental management, eds. Ulrich Steger, Zhaoben Fang and Wei Lu. Sheffield, UK: Greenleaf Publishing.

Hoffman, Andrew J. 2001. "Linking organizational and field-level analyses: The diffusion of corporate environmental practice." Organization \& Environment 14(2):133-158.

Hughes, Neil C. 2002. China's Economic Challenge: Smashing the Iron Rice Bowl. New York: M.E. Sharpe Inc.

Li \& Fung Research Centre. 2005. "China's eleventh five-year program - implications for doing business in China." In Li \& Fung Research Centre: China Distribution \& Trading. Hong Kong: Li \& Fung Research Centre.

Lincoln, N.K. and E.G. Guba. 2000. "Paradigmatic controversies, contradictions, and emerging confluences." In Handbook of qualitative research, ed. N K and Lincoln Denzin, Y S. Thousand Oaks, C.A.: Sage Publications.

Lincoln, Y S and E G Guba. 1985. Naturalistic Inquiry. Beverly Hills: Sage.

Liu, Xianbing and V. Anbumozhi. 2009. "Determinant factors of corporate environmental information disclosure: an empirical study of Chinese listed companies." Journal of Cleaner Production 17(6):593-600.

Ma, Xiaoying and Leonard Ortolano. 2000. Environmental Regulation in China: Institutions, Enforcement, and Compliance. Maryland, USA: Rowman \& Littlefield Publishers.

Mathews, M.R. 1997. "Twenty-five years of social and environmental accounting research Is there a silver jubilee to celebrate?" Accounting, Auditing \& Accountability Journal 10(4):481.

Oliver, Christine. 1991. "Strategic Responses to Institutional Processes." Academy of Management Review 16(1):145-179.

Parker, Lee D and Bet H Roffey. 1997. "Methodological themes Back to the drawing board: revisiting grounded and the everyday accountant's and manager's reality." Accounting, Auditing \& Accountability Journal 10(2):212-247.

Poland, B. D. 1995. "Transcription quality as an aspect of rigour in qualitative research." Quality Inquiry 1(3):290-310.

Ross, Lester. 1994. "The next wave of environmental legislation." The China Business Review 21(4):30-33.

Rowe, Anna. 2006. "Looking through the Chinese 'lens' of corporate environmental management." Journal of International Business Strategy 4(1):105-112.

Rowe, Anna L. and James Guthrie. 2007. "Corporate environmental reporting: informal institutional norms." In 6th Australasian centre for social and environmental accounting research (CSEAR) conference, The University of Sydney,

Rowe, Anna. 2008. "Evolutionary epic of 'greening' Chinese dragons' management institutions." International Journal of Business Research 8 (1): 125-132.

SCNPC. 2005. "The Renewable Energy Law of the PRC." In Standing Committee of National People's Congress or China. Beijing: Standing Committee of National People's Congress or China.

SEPA. 2003. "Bulletin on Information Disclosure of Corporate Environmental Performance." Beijing: State Environmental Protection Administration.

Shrivastava, P. 1995. "Ecocentric management for a risk society." Academy of Management Review 20(1):118-137.

Stover, Jim. 2000. "China's environmental framework 2000 and beyond." The China Business Review 27(2):48-54. 
Strauss, A. L. and J. Corbin. 1990. Basics of Qualitative Research: Grounded Theory Procedures and Techniques. London: Sage.

Strauss, A. L. and J. Corbin. 1994. "Grounded theory methodology: An overview." In Politics and Ethics in Qualitative Research, ed. N. K. \& Lincoln Denzin, Y. S. Thousand Oaks, CA.: Sage.

Tan, J.J. and R.J. Litschert. 1994. "Environment-strategy relationship and its performance implications: an empirical study of the Chinese electronics industry." Strategic Management Journal 15:1-20.

Tang, Shui-Yan , Carlos Wing-Hung Lo, Kai-Chee Cheung and Jack Man-Keung Lo. 1997. "Institutional constraints on environmental management in urban China: Environmental impact assessment in Guangzhou and Shanghai." The China Quarterly(152):863-875.

Tolbert, Pamela S and Lynne G Zucker. 1983. "Institutional sources of change in the formal structure of organizations: The diffusion of civil service reforms 18801935." Administrative Science Quarterly 23:22-39.

Tsai, S H Terence and John Child. 1997. "Strategic Responses of multinational corporations to environmental demands." Journal of General Management 23(1):1-24.

Wang, Hua, Jun Bi, David Wheeler, Jinnan Wang and et al. 2004. "Environmental performance rating and disclosure: China's GreenWatch program." Journal of Environmental Management 71(2):123-133.

Whiteley, A. 2004. "Grounded Research: A modified grounded theory for the business setting." Qualitative Research Journal 4(1).

Whiteley, A., Sara Cheung and Zhang Shi Quan. 2000. Human resource strategies in China. Singapore: World Scientific.

Wong, Koon-Kwai and Hon S. Chan. 1996. "The environmental awareness of environmental protection bureaucrats in the People's Republic of China." the Environmentalist 16:215.

World Bank. 1997. Clear Water, Blue Skies, China's Environment in the New Century. China 2020 Series Edition. Washington, D.C.: World Bank.

World Bank. 2001. "China: air, land and water: environmental priorities for a new millennium." Washington, DC: The World Bank.

Zhang, Bing, Jun Bi, Zengwei Yuan, Junjie Ge, Beibei Liu and Maoliang Bu. 2008. "Why do firms engage in environmental management? An empirical study in China." Journal of Cleaner Production 16(10):1036-1045.

Zhang, Kun-min and Zong-guo Wen. 2008. "Review and challenges of policies of environmental protection and sustainable development in China." Journal of Environmental Management 88(4):1249-1261.

Zhang, S Q. 1997. "The economic instruments for sustainable development." In Introduction to sustainable development. Beijing: China's Environmental Sciences Publishing House.

Zhang, Shi-Qui. 2001. "Environmental regulatory and policy framework in China: an overview." Journal of Environmental Science 13(1):122-128.

Zhang, Weijiong, Ilan Vertinsky, Terry Ursacki and Peter Nemetz. 1999. "Can China be a clean tiger?: Growth strategies and environmental realities." Pacific Affairs 72(1):23-37. 